\title{
PEMBELAJARAN PENEMUAN SUMBER ENERGI LISTRIK ALTERNATIF TERBARUKAN UNTUK MENINGKATKAN KREATIFITAS DAN AKTIFITAS SISWA PADA PEMBELAJARAN FISIKA
}

\author{
Festiyed, Desmalinda \\ ${ }^{1)}$ Staf Pengajar Jurusan Fisika, FMIPA Universitas Negeri Padang \\ ${ }^{2)}$ Guru SMA N 10 Padang \\ Keterangan Penulis ${ }^{2)}$ \\ ${ }^{2)}$ Keterangan Penulis ${ }^{3)}$ \\ Festiyed@gmail.com,des_malinda@yahoo.com
}

\begin{abstract}
Materi sumber-sumber energi dan energi alternatif, pada pembelajaran Fisika kelas XII di SMA, menuntut siswa untuk dapat memahami dan memperoleh kompetensi belajar lewat pengalaman langsung, yang didasari konsep learning by doing. Pada kesempatan ini, peneliti mencoba mencari sumber-sumber energi alternatif terbarukan lainnya, salah satunya adalah dari tape singkong, dengan tujuan untuk memberikan pengalaman belajar pada siswa, menemukan dan mengembangkan ide-ide kreatif, inovatif dan meningkatkan aktivitas siswa pada pembelajaran fisika, untuk menemukan sumber-sumber energi alternatif terbarukan lainnya yang berada disekitar siswa. Pembelajaran ini dapat dilakukan melalui pendekatan inkuiri dengan langkah-langkah : merumuskan masalah, merumuskan hipotesiss, mengumpulkan data, menguji hipotesis, merumuskan kesimpulan.

.Hasil penelitian menunjukan bahwa dengan memberikan materi sumber energi alternatif terbarukan dari tape singkong didapatkan kuat arus yag dihasilkan dengan satu sel 0,7 Volt dan kuat arus untuk satu sel kurang lebih 1,5 mA, dengan dibuat hubungan seri dan parel sel-sel tapai yang sudah dibuat dapat menghidupkan lampu led atau mencas Hp. Dari hasil ini siswa mempunyai ide kreatif, inovatif dan aktifitas menemukan sumber energi listrik alternatif lainnya dari bahan bahan yang ada disekitar siswa. Bahan yang dapat dijadikan sumberenergi listrik alternatif adalah yang mengandung asam, basa, energi, gula, garam.
\end{abstract}

Keywords : Sumber Energi Listrik Alternatif Terbarukan, Kreatifitas dan Aktifitas.

\section{PENDAHULUAN}

Indonesia kaya sumber daya alam dan sumber daya manusia, untuk mengolah sumber daya alam yang melimpah diperlukan sumber daya manusia yang berkualitas maka pemerintah melalui program pendidikan berupaya meningkatan mutu dan kualitas pendidikan karena merupakan proses pengembangan potensi diri peserta didik yang dilakukan secara sadar dan terprogram sehingga peserta didik memiliki kompetensi spiritual, intelektual, emosional, keterampilan dan karakter sesuai dengan standar kebutuhan masyarakat.(Alberida, Lufri, 
Festiyed, \& Barlian, 2018). Pendidikan program utama setiap negara untuk peningkatan kualitas sumber daya manusia, dan berfungsi untuk menjaga eksistensi diri dalam pergaulan antar bangsa. setiap negara memposisikan pendidikan sebagai dasar peningkatan kualitas sumber daya manusia dan kualitas kehidupan bangsa. Pendidikan di sekolah dimulai dari pembelajaran di kelas, guru berperan penting dalam peningkatan kualitas dan mutu pembelajaran dikelas terkait tugas pokok dan fungsi guru sebagai pendidik salah satunya adalah menyelenggarakan pembelajaran aktif, efisien, kreatif, efektif dan menyenangkan dan learning by doing. Namun saat ini masih banyak guru yang mengajar secara konvensional. Fisika salah satu mata pelajaran di sekolah menegah atas diharapkan siswa memiliki kompetensi sikap positif, berkarakter dengan daya pikir kritis, kreatif, inovatif, kolaboratif, jujur dan terbuka. Kompetensi pengetahuan memahami fenomena, konsep, prinsip gejala alam melalui materi-materi Fisika, kompetensi keterampilan mengambil keputusan di antara berbagai pilihan yang bersifat ilmiah; memahami dampak dari perkembangan Fisika terhadap perkembangan teknologi dan memecahkan persoalan sehari-hari (Festiyed, Djamas, \& Pilendia, 2018).

Namun dalam kenyataan sehari-hari sebagaian besar siswa menganggap ilmu Fisika sulit banyak turunan rumus, monoton dengan teori-teori dan membosankan tidak ada kreatifitas dan aktifitas yang menyenakan karena pada pembelajaran Fisika di kelas masih banyak guru menggunakan metode konvensional ceramah. Guru fisika sebagai disainer fasilitator pembelajaran fisika di kelas harusnya mampu merancang dan melaksanakan pembelajaran berpusat pada siswa di kelas, sehingga siswa memahami konsep, berperan aktif, kreatif, inovatif dan menyenangkan. Siswa dapat belajar lebih mudah tentang konsep-konsep yang bersifat nyata dan dapat diamati melalui pancainderanya, melakukan peristiwa alam nyata learning by doing. (Jannah \& Kiram, 2018)

Pada mata pelajaran Fisika kelas XII semester I pada materi listrik dinamis dipelaari sumber-sumber energi searah, hukum Ohm dan hukum koirchoff. Pada pembelajaran kali ini penulis menyajikan ide/gagasan mencari ssumber-sumber energi listrik terbarukan dari tape singkong untuk menjawab masalah keterbatasan energi yang berasal dari fosil.

Pada kesempatan ini penulis mencoba dalam pembelajaran Fisika dikelas memberikan ide mengembangkan sumber energi alternatif terbarukan dengan sumber energi listrik alternatif terbarukan dari tape Singkong dipadu dengan model pembelajaran inkuiri. Strategi Pemecahan Masalah : 
a. Guru menyusun perangkat pembelajaran, 1. Rencana pelaksanaan pembelajaran (RPP), 2. Lembar kerja peserta didik (LKPD) sumber energi listrik alternatif terbarukan dari tape singkong, 3. bahan ajar rangkaian energi listrik

b. Memvalidaasi perangkat pembelajaran pada ahli dan pakar

c. Praktikalitas dengan siswa melakukan percobaan sumber energi listrik alternatif terbarukan dari tape singkong.

d. Siswa melakukan ekperimen didalam pembelajaran untuk mengumpulkan data berapa besar arus listrik dan tegangan yang didapat dari hasil ekperimen dan mengambil kesimpulannya.

e. Siswa diberi tugas proyek untuk mencari sumber energi listrik alternatif terbarukan lainnya.

Pada tahap implementasi ini siswa melakukan percobaan mendapatkan sumber energi listrik alternatif terbarukan dari tape singkong.

A. Alat dan bahan :

\begin{tabular}{|l|l|l|l|l|l|}
\hline No & Alat / Bahan & Jumlah & No & Alat / Bahan & Jumlah \\
\hline 1. & Tape singkong & I Kg & 6. & Tang & 1 buah \\
\hline 2. & Kabel tembaga & $6 \mathrm{~m}$ & 7. & Multimeter & 1 buah \\
\hline 3. & $\begin{array}{l}\text { Lempengan seng } \\
\text { ukuran 20cmx10cm }\end{array}$ & 4 Lembar & 8. & Celas Kimia & 5 buah \\
\hline 4. & Kabel & Secukupnya & 8. & Neraca Ohaus & 1 buah \\
\hline 5. & Lampu led & 6 buah & 10. & Air & Secukupnya \\
\hline
\end{tabular}

Sumber-sumber energi dapat kita bedakan menjadi sumber energi tebarukan yang dapat diperbaharui yang berasal dari alam dan sumber energi tak terbarukan yang tak dapat diperbaharui seperti yang berasal dari fosil,salah satu energi terbarukan adalah biofuel berasal dari tumbuh — tumbuhan alam yang mengandung gula dan energi.

Tape singkong salah satu makanan tradisional indonesia yang dapat dijumpai di setiap daerah di indonesia dengan nama yang berbeda-beda. Kandungan tape singkong adalah gula, 173 kkal setiap 100 gr tape maka tape singkong dapat digunakan sebagai sumber energi listrik alternatif terbarukan biofuel. Untuk mendapatkan besar arus dan tegangan yang diinginkan tape singkong bisa kita buat menjadi beberapa cell dan di rangkai menjadi rangkaian listrik sederhana. 


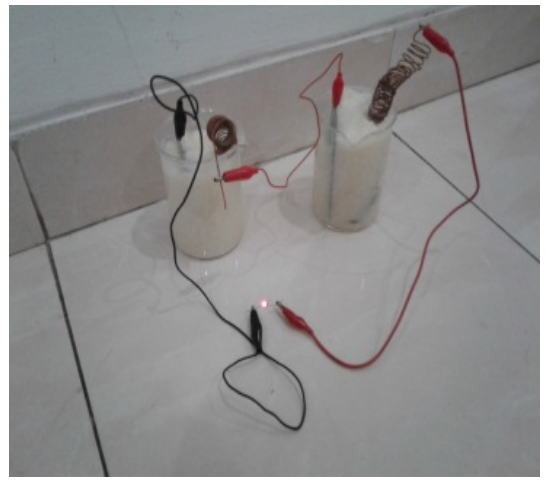

Rangkaian listrik sederhana merupakan suatu rangakaian listrik tertutup yang dapat dialiri oleh arus listrik terdiri dari sumber energi listik / tegangan untuk membuat arus mengalir, memiliki penghantar, memiliki alat energi listrik, dan merupakan rangkaian tertutup.

Gambar.1. Rangkaian listrik sederhna

Pada saat ini kita menggunakan tape sebagai sumber energi listrik alternatif terbarukan. Untuk memperbesar arus listrik dari tape kita bisa merangkai paralel cell-cell tape, dan untuk memperbesar tegangan sesuai keinginan kita dapat merangkai seri cel-cell tape sesuai dengan persamaan berikut

Rangkain seri sumber tegangan : $C=C+C+C=n €$

Rangkaian paralel teganagan $\mathrm{i}=\Sigma \frac{\mathrm{E}}{n r}$

Untuk menyelidiki besarnya arus dan tegangan yang terdapat dalam satu cell tape dilakukan secera inkuiri, Inkuiri berarti pemeriksaan atau penyelidikan. Menurut Sanjaya $(2006,194)$ "Pembelajaran Inkuiri adalah rangkaian kegiatan pembelajaran yang menekankan pada proses befikir secara kritis dan analitis untuk mencari dan menemukan sendiri dari suatu masalah yang di pertanyakan.” Pembelajaran Inkuiri menekankan untuk berpikir ilmiah menurut metode ilmiah mengajak siswa untuk melakukan hal serupa yang dilakukan oleh ilmuwan dalam usaha mereka untuk mengorganisir pengetahuan dan membuat prinsip-prinsip. Langkah-langkah pembelajaran Inkuiri adalah : merumuskan masalah, merumuskan hipotesiss, mengumpulkan data, menguji hipotesis, merumuskan kesimpulan. 


\section{METODE PENELITIAN}

Langkah pelaksanaan praktikum :

1. Timbanglah 150 gram tape masukkan

kedalam gelas kimia, tambahkan air

secukupnya lalu aduk sampai rata.

Gambar 2. Tape

2. Potong kawat tembaga $150 \mathrm{~cm}$ bersihkan pelapis isolatornya, lalu gulung dan potong seng $10 \mathrm{~cm} \times 20 \mathrm{~cm}$ seperti gambar
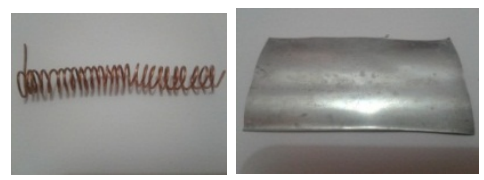

3. Masukkan gulungan kawat tembaga dan seng ke dalam cell tape

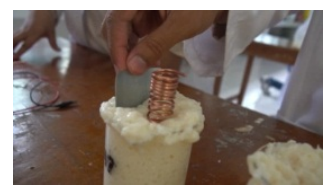

4. Hubungkan kabel merah ke tembaga sebagai kutup positif dan kebel hitam ke kutup negatif, catat berapa kuat arus dan tegangan yang didapat untuk satu cell tape.
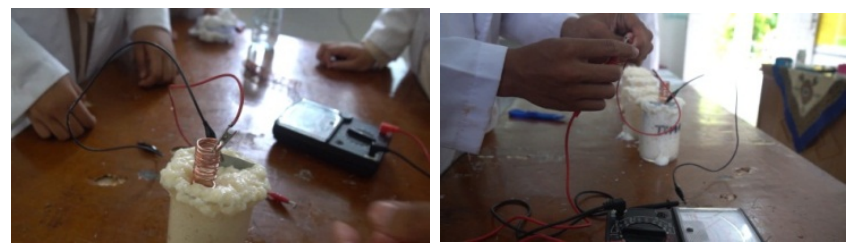

5. Susunlah 2 cell tape secara seri untuk mendapat ka teganagan yang diinginkan untuk dapat menghidupkan lampu led, catat tegangan dan kuat arus yang didapat setelh diserikan, lalu hubungkan ke lampu led.

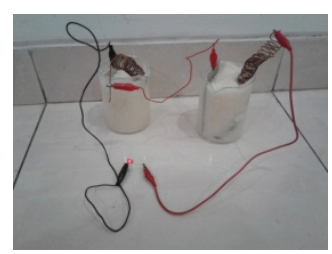

6. Diskusikan hasil yang didapat dalam kelompok, isi pertanyaan dalam LKS, ambil kesimpilan dan presentasikan didepan kelas hasil yang didapat.

Dalam pelaksanaan pembelajaran dikelas menggunakan model pembelajaran Inkuiri guru menyiapkan masalah bagi siswa dan pertanyaan pertanyaan penuntun agar dapat melakukan 
eksperimennya. siswa melakukan percobaan-percobaan untuk mengambil data menjawab hipotesis yang diajukan. pertanyaan-pertanyaan dari guru yang telah disusun dalam lembar kerja siswa memegang peranan penting mengumpilkan data. Pertanyaan guru meminta siswa berfikir tingkat tinggi menggunakan kemampuan keterampilan proses. Dengan demikian partisipasi penuh dari siswa dalam proses pembelajaran dapat dicapai dengan baik.

Dalam penelitian ini penulis menggunakan instrument penelitian dan metode pengumpulan data dari beberapa jenis instrument antara lain angket atau kuesioner, pedoman observasi. Pretes dan Post-tes.

Metode pengumpulan data menggunakan : Angket, Observasi, dan Tes.

Perangkat Pembelajaran yang telah divalidasi dan direvisi diujicobakan dalam proses pembelajaran. Berdasarkan data yang diperoleh dari hasil uji coba maka akan diketahui praktikalitas dan efektivitas model pembelajaran.

\section{Teknik Analisa Data}

Teknik analisa data yang digunakan adalah statistik deskriptif untuk mendeskripsikan tingkat validitas Pembelajaran. Analisis validitas perangkat pembelajaran langkah-langkahnya sebagai berikut:

1. Penskoran untuk digunakan skala Likert, skor 1 sampai 4, dengan ketentuan sebagai berikut:

Tabel 1. Kategori dan Skor Skala Likert

\begin{tabular}{|l|l|l|l|}
\hline No & Skor & Kategori & Keterangan \\
\hline 1 & Skor 4 & sangat setuju & \\
\hline 2 & Skor 3 & setuju & \\
\hline 3 & Skor 2 & tidak setuju & \\
\hline 4 & Skor 1 & sangat tidak setuju & \\
\hline
\end{tabular}

2. Menjumlahkan skor tiap validator untuk seluruh butir angket

3. Menjumlahkan skor untuk seluruh validator

4. Penilaian validator dilakukan dengan cara melihat skor minimum dan skor maksimum yang diperoleh, 10 item yang di validasi oleh 5 orang validator skor minimum dan skor maksimumnya adalah sebagai berikut.

Skor minimum adalah $5 \times 10 \times 1=50$

Skor maximum adalah $5 \times 10 \times 4=200$

5. Untuk menentukan kiteria prosentase per-item menggunakan rumus:

$$
P=\frac{\sum \text { Skor per item }}{\text { Skor maks Xn validator per item }} X 100 \%
$$


Tabel 2. Kategori validasi bahan ajar oleh validator

\begin{tabular}{|l|l|l|}
\hline No & Nilai(\%) & Katogori \\
\hline 1 & $0-20$ & Tidak valid \\
\hline 2 & $21-40$ & Kurang valid \\
\hline 3 & $41-60$ & Cukup valid \\
\hline 4 & $61-80$ & Valid \\
\hline 5 & $81-100$ & Sangat Valid \\
\hline
\end{tabular}

Dimodifikasi dari Departemen Pendidikan Nasional (2000:180),Depdiknas menyimpulkan rentang bobot kategori adalah sebagai berikut:

1. Menuliskan kesimpulan bahwa perangkat pembelajaran layak, jika nila total $\geq 75$ dengan bobot $\mathrm{x}$ nilai sub kriteria materi $\geq 75$.

2. Menuliskan kesimpulan bahwa perangkat pembelajaran tidak layak, jika nilai total $\leq 75$ dengan bobot $\mathrm{x}$ nilai sub criteria materi $\leq 75$

\section{HASIL DAN PEMBAHASAN}

Berdasarkan hasil pengumpulan data dari penelitan sumber energi listrik alternatif terbarukan dari tape didapatkan untuk satu cell tape didapatkan kuat arus listrinya antara 0.7 dan 0,8 miliamper dan tegangan yang didapatkan 1.5 milivoll, untuk satu cell tape belum ampu menghidupkan lampu led, maka untuk dapat menghidupkan lampu led maka cell tape dirangkai seri untuk memperbesar tengangannya, setelah dirangkai seri maka didapatkan kuat arusnya tetap 0,7 miliamper dan tegangannya menjadi 3 milivolt keadaan ini sudah dapat menghidupkan lampu led. Dengan hasil yang didapatkan siswa aktivitas siswa meningkat, siswa berkreatifitas untuk menemukan ide lain menemukan sumber energi listrik alternatif laiinya, untuk tugas rumahnya siswa diminta menemukan sumber energi listrik lainnya dan menerapkannya dlamkehidupan sehari-hari. 


\section{KESIMPULAN}

Dari penelitian yang dilakukan dapat diambil simpulan sebagai berikut :

1. Dihasilkan perangkat pembelajaran Fisika pengembangan sumber energi dari tape singkong menggunakan model pembelajaran inkuiri dalam bentuk rencana pelaksanaan pembelajaran, lembar kerja siswa dan bahan ajar.

2. Berdasarkan data hasil percobaan tape dapat digunakan sebagai sumber energi listrik alternatif terbarukan karena menghasilkan arus listrik dan beda potensial yang dapat digunakan untuk mencas HP dan menghidupkan lampu led.

3. Pembelajaran fisika sumber energi terbarukan dari tape singkong dengan model pembelajaran inkuiri dapat membuat siswa kreatif, inovativ dan aktif dalam pembelajaran. Berdasarkan hasil penelitian ini dapat direkomendasikan :

1. Pembelajaran sumber energi listrik alternatif terbarukan dari tape singkong dengan model pembelajaran inkuiri dapat dilakukan dan diterapkan oleh teman guru yang lain dengan mudah.

2. Pembelajaran sumber energi listrik alternatif terbarukan dari tape singkong dengan model pembelajaran inkuiri dapat menjadi reverensi bagi guru untuk mengaktifkan, meningkatkan kreatifitas dan inovasi siswa dalam pembelajaran.

\section{DAFTAR PUSTAKA}

Alberida, H., Lufri, Festiyed, \& Barlian, E. (2018). Problem Solving Model for Science Learning. In IOP Conference Series: Materials Science and Engineering. https://doi.org/10.1088/1757$899 \mathrm{X} / 335 / 1 / 012084$

Festiyed, Djamas, D., \& Pilendia, D. (2018). Implementation Authentic Task to Enhance Problem Solving and Self-Management for Physics College Students. IOP Conference Series: Materials Science and Engineering, 335, 012068. https://doi.org/10.1088/1757-899X/335/1/012068

Jannah, S. M., \& Kiram, Y. (2018). Validity and Practitality of Acid-Base Module Based on Guided Discovery Learning for Senior Validity and Practitality of Acid-Base Module Based on Guided Discovery Learning for Senior High School. https://doi.org/10.1088/1757-899X/335/1/012097

Sanjaya, Wina. 2006. Strategi Pembelajaran Berorientasi Standar Proses Pendidikan. Jakarta: Kencana Prenada Media.

Jakaria, Yaya. 2009. Uji Coba Model (Validasi). Jakarta: Pusat Penelitian Kebijakan Dan Inovasi Pendidikan Badan Penelitian Dan Pengembangan Departemen Pendidikan Nasional. 
Sanjaya, Wina. 2006. Strategi Pembelajaran Berorientasi Standar Proses Pendidikan. Jakarta: Kencana Prenada Media. 